An occasional experiment along some other line has not been enough to obscure the general trend; indeed, the speedy scrapping of such failures only emphasises the idea of a determined plan. But closer consideration shows that the course of the development was guided simply by the laws of mechanics and economics and by the history of discovery in other branches of science. That alone was the nature of the determination, and predetermination there was none. From these instances we see that selection can, indeed must, produce just that evolution along definite lines which is the supposed feature of orthogenesis.

The arguments for orthogenesis are reduced to two: first, the difficulty of accounting for the incipient stages of new structures before they achieve selective value; and, secondly, the supposed cases of non-adaptive, or even-as one may term it-counteradaptive, growth.

The earliest discernible stage of an entirely new character in an adaptive direction is called by $\mathrm{H}$. F. Osborn a "rectigradation" (I907), and the term implies that the character will proceed to develop in a definite direction. Osborn gives as instances the first folding of the enamel in the teeth of the ancestral horses and the first slight elevation on the skull of the older Titanotheres, foreshadowing the large nosehorns of those strange Tertiary mammals. He contrasts rectigradations with the changes in shape and proportion of some pre-existing structure, and calls the latter "allometrons." Further, he claims that some predetermining law or similarity of potential governs the appearance of rectigradations, because they arise independently on the same part of the skull in different tineages at different periods of geological time.

Osborn maintains, then, that rectigradations are a result of the principle of determination, but this does not seem necessary. In the first place, the precise distinction between an allometron and a rectigradation fades away on closer scrutiny. When the rudiment of a cusp or a horn changes its form, the change is an allometron; the first swelling is a rectigradation. But both of these are changes in the form of a preexisting structure; there is no fundamental difference between $a$ bone with an equable curve and one with a slight irregularity of surface. Why may not the original modification be due to the same cause as the succeeding ones? The development of a horn in mammalia is probably a response to some rubbing or butting action which produces changes first in the hair and epidermis. One requires stronger evidence than has yet been adduced to suppose that in this case form precedes function. As Jaelsel has insisted, skeletal formation follows the changes in the softer tissues as they respond to strains and stresses. In the evolution of the Echinoid skeleton any new structures that appear, such as auricles for the attachment of jaw-muscles and notches for the reception of external gills, have at their inception all the character of rectigradations, but it can scarcely be doubted that they followed the growth of their correlated soft parts, and that these latter were already subject to natural selection. But we may go further; in vertebrates, as in Echinoderms, the bony substance is interpenetrated with living matter, which renders it directly responsive to every mechanical force, and modifies it as required by deposition or resorption, so that the skeleton tends continually to a correlation of all its parts and an adaptation to outer needs.

The fact that similar structures are developed in the same positions in different stocks at different periods of time is paralleled in probably all classes of animals; Ammonites, Brachiopods, Polyozoa, Crinoids, and Sea-urchins present familiar instances. But do we want to make any mystery of it? The words "pre- disposition," "predetermining law," "similarity of potential," "inhibited potentiality," and " periodicity" all tend to obscure the simple statement that like causes acting on like material produce like effects. When other causes operate the result is different. Certainly such facts afford no evidence of predetermination in the sense that the development must take place willy-nilly. Quite the contrary; they suggest that it takes place. only under the influence of the necessary causes.

The resemblance of the cuttle-fish eye to that of a vertebrate has been explained by the assumption that both creatures are descended, longo intervallo no doubt, from a common stock, and that the flesh or the germ of that stock had the internal impulse to produce this kind of eye some day when conditions should be favourable. It is not explained why many other eyed animals, which must also have descended from this remote stock, have developed eyes of a different kind. Nevertheless, I commend this hypothesis of Prof. Bergson to the advocates of predisposition. To my mind, it only shows that a philosopher may achieve distinction by a theory of evolution without a secure knowledge of biology.

When the same stock follows two quite different paths to the same goal it is impossible to speak of a predetermined course. [An instance of this was given.]

(To be continued.)

\section{The Constitution of Cellulose.}

$\mathrm{N}$ an illuminating lecture delivered before the 1 French Chemical Society on May 2I, Prof. A. Pictet, of Geneva, described the results obtained by his pupils and himself on distilling cellulose at a low pressure, and showed how these can be interpreted so as to throw much new light on the constitution of this complicated substance.

When cotton cellulose is heated gradually in a distilling apparatus under a pressure of $x^{-1} 5 \mathrm{~mm}$. decomposition begins at $210^{\circ}$ and an oil distils over equal in weight to 45 per cent. of the original cellulose, which soon solidifies, and consists of lævoglucosan. This is considered to be an anhydride derived from $\beta$-glucose, and to have the constitution<smiles>OCC1OCC(C(O)O)OC1C(O)O</smiles>

Previous work has shown that cellulose furnishes on acetolysis a disaccharide, cellobiose, which probably contains an $\alpha$-glucose and a $\beta$-glucose group. Also, with hydrobromic acid, cellulose gives bromomethylfurfurol. The origin of the latter, a hydrofuran nucleus containing two side-chains, the author terms the chitose grouping. Prof. Pictet therefore regards cellulose as containing two $\beta$-glucose groups, one chitose grouping, and probably an a-glucose group, represented thus:

$$
\frac{\beta \mid C h}{\beta \mid a ?}
$$

By acetolysis the $\alpha$-glucose group and a $\beta$-glucose group together form cellobiose (50 per cent.), and in the decomposition with hydrobromic acid the chitose grouping furnishes bromomethylfurfurol (25 per cent.), the other three groups being converted into the black mass which is always formed in the reaction. Finally, on dry distillation under reduced pressure the $\beta$-glucose groupings split off to give lævoglucosan (50 per cent.),

No. 2657 , vOL. IO6] 
and the others, which are not volatile without decomposition, furnish water, furfurol, carbon, etc.

In the molecule of cellulose the various groups are probably united together in consequence of the opening of the ring at an oxygen atom which does not form the furan ring, and in this way the cellulose molecule, forming a vast cyclic network, may bear some analogy to those of the albuminoids, in which the linking agents are nitrogen atoms.

\section{Joseph Black and Belfast.}

UNDER the title of "Joseph Black: His Belfast Friends and Family Connections", Mr. Henry Riddell has recently published in the Proceedings of the Belfast Natural History and Philosophical Society (vol. iii., $1919^{-20}$, p. 49) an interesting account of Joseph Black's connection with Belfast. As is well known, the famous chemist was born at Bordeaux, where his father, John Black, was a factor and wine merchant, but his ancestors for many generations back were Ulstermen, and he himself received his school education either in the old Latin School in Belfast, endowed by Earl Donegall in 1666, or at the hands of a Mr. Sprott, a schoolmaster of repute in that city. Up to the age of twelve Black was educated by his mother, Margaret Gordon, who is described as a woman of great force of character and many accomplishments. She was the daughter of Robert Gordon, a merchant of Aberdeen, and was married to John Black in I7 I6, by whom she had issue eight sons and five daughters, Joseph Black, who was born in 1728 , being the fourth son.

The Blacks were of Scottish extraction, and were said to be descended from a member of the Clan Lamont who was known as Gillie-dhu on account of his remarkably black hair. Some of his sons, on the invitation of James I., passed over to Ulster, which had been laid waste and depopulated by the wars among the Irish chiefs and their clans. Their descendants, or some of them, settled in Belfast and anglicised their name to Black. One of them, John Black, the great-grandfather of the chemist, fought as a trooper against Cromwell. His son, also John Black, born in 1682 , was a burgess of Belfast, and had a family of five sons, all engaged in "merchandysinge" in various parts of the Continent. The various members married into some of the leading Ulster families-the Eccles, Wilsons, Banks, Legges, Clarkes, and others. Jane Eccles, the grandmother of the chemist, was the daughter of John Eccles of Cranmore, who entertained William III. on his way from Carrick to Drogheda. The chemist's eldest brother, John, married Jane Banks, a member of one of the best-known families in Belfast. One of their granddaughters, Maria, became the wife of Lord Downs, and from them sprang two girls, Ann and Charlotte, who married respectively Lord Clonmel and Lord Seaton. Isobel Black, the sister of the chemist, married James Burnett, of Aberdeen; their daughter became the wife of Adam Ferguson, the moral philosopher and colleague, intimate friend, and cousin of Joseph Black. A descendant of one of his other sisters, Katherine, became the wife of Prince Waldeck and Pyrmont.

Two of Joseph's brothers, Samuel and George, returned to Belfast and took a prominent part in the municipal life of the town, holding the office of "Sovereign" (mayor) between them no fewer than seven times between 1772 and 1789 .

Joseph Black, after a good grounding in classics and mathematics, left Belfast for Glasgow in his eighteenth year, entering the University, therefore, NO. 2657 , VOL. IO6] considerably older than the usual run of matriculants at that period. He came almost immediately under the influence of two remarkable men, Dick, professor of natural philosophy, and Cullen, professor of medicine and lecturer on chemistry. The fact that Black was considerably senior to the majority of his fellowstudents may have induced Cullen to offer him the position of lecture-assistant, and it was probably this fortunate circumstance that determined his career.

The great chemist, who died in 1799 , was never married, and left no immediate descendants. It is evident from this short statement that he belonged to a family of noteworthy mental peculiarities, many members of which were characterised by remarkable powers and capacity. Joseph Black, so far as is known, is the only one who showed any striking predilection towards scientific pursuits, and there are special circumstances in his case which may serve to explain the direction of his inclinations. If, as the late Sir Francis Galton contended, high reputation is a pretty accurate test of high ability, Joseph Black certainly ennobled his ancestry. But an examination of their individual history seems to show that he is no less a debtor to those who went before him, and that his eminence is in no small degree due to qualities implanted in him by his Ulster upbringing and associations.

T. E. THORPE.

\section{The Sakura-jima Eruption of I9I4.}

PROF. OMORI has recently made two additions to his valuable series of memoirs on the eruption of the Sakura-jima (South Japan) on January 12, I914. The fourth memoir deals with the continued changes of elevation in the neighbourhood of the volcano, and the fifth with the numerous earthquakes which preceded and followed the eruption (Bull. Imp. Earthq. Inves. Com., vol. viii., 1920, pp. 323-51 and $353-466)$. Until I9I4 the Sakura-jima was an island in the Bay of Kagoshima, the inner bay to the north of it being a basin $12 \frac{1}{2}$ miles long from east to west and $7 \frac{1}{2}$ miles wide. A comparison of two series of levels made a few years before the eruption and in April and May, I9I5, revealed a depression of not less than 20 in. in the northern part of the bay, and of from' I ft. to $5^{\frac{1}{2}} \mathrm{ft}$. round the coast of the former island, the centre of which was elevated in two places by as much as $30 \mathrm{ft}$. and $4 \mathrm{I} \mathrm{ft}$. In the winter of I9r8-19 a new series of levels was made along the west and north coasts of the bay, from which it is seen that the depression of the inner bay gave place to an elevation, the mean rise from February, I9I5, to December, I9I 8 , being about 4 in. In I9 I7 a series of soundings was also made in the bay, and these show that there are three depressions (of maximum depth 85 , I 13 , and 79 fathoms), the first being separated from the others by a submarine ridge running north from the volcano, and apparently due to the eruptions of A.D. $764,1468-76$, and 1779 . Comparing the new soundings with those made in Igo6, there are seen to be three areas of fresh depression (from 3 to 4 fathoms) coinciding with the three depressions, and two areas of new elevation, the more important one (of 3 fathoms) being near the submarine ridge. Prof. Omori estimates that the total resultant depression of the district amounts to about one-quarter of a cubic mile, and the volume of lava and ashes ejected to slightly more than one-half of a cubic mile, and he suggests that this difference may account for the defect of gravity sometimes observed in the neighbourhood of a volcano.

The records of the Sakura-jima earthquakes at

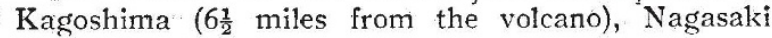

